\title{
sciendo
}

AGNIESZKA MARZEC ${ }^{1}$, MICHAŁ SKRZYPEK' ${ }^{1}$, ZBIGNIEW MARZEC ${ }^{2}$

\section{Dietary supplements as a challenge for contemporary public health: scale of the phenomenon, health risk, legal regulations}

\begin{abstract}
The subject of the study is to present the issues of dietary supplements from the perspective of public health, taking into account definitional problems, the scale of the phenomenon in Poland and the look at the problem in question from the sociomedical perspective emphasizing the use of dietary supplements as a form of self-care. The study also discusses selected legal regulations in Poland and the EU on marketing and trading in dietary supplements. The article also presents, from the perspective of pharmaceutical sciences, the proposals for classification of dietary supplements and selected issues concerning safety of their use. The subject of a part of the present analysis is also the recent data showing the wide popularization of the phenomenon of polypragmasia consisting in simultaneous use of dietary supplements and OTC pharmaceutical agents with prescription drugs in Poland.
\end{abstract}

Keywords: dietary supplements, health risk, public health.

DOI: $10.2478 /$ pjph-2018-0006

\section{INTRODUCTION}

Dietary supplements complement a regular diet based on traditional food products. A proper and diversified diet should provide all the components necessary for body functioning. However, diets of some parts of the society are unhealthy, what is likely to lead to dietary deficits or overconsumption, and thereby to various nutrition-related diseases. The rational use of supplements (i.e. multivitamin preparations, mineral compounds and other substances considered essential for proper human development and prevention of diseases) is aimed to strengthen health and maintain homeostasis. Otherwise, their uncontrollable use can be ineffective when there are no vitamin or mineral deficiencies, but - more importantly - may also be harmful. In many cases, dietary supplements ought to be considered the therapeutic products which should be used only in strictly defined clinical situations, preferably under control of a physician or pharmacist. In this review it will be stressed that drugs and dietary supplements used simultaneously can induce many adverse side effects that can lead to severe complications $[1,2]$.

The goal of the study written from the perspective of the clinical dietetics is to present selected problems concerning the use of dietary supplements in Polish society, taking account of the scale of the phenomenon and health risk associated with the use of dietary supplements not in accordance with the recommendations formulated in the EBM paradigm. Attention will also be drawn to the use of dietary supplements as a form of self-treatment, and selected legal regulations on marketing and trading in dietary supplements will be discussed. The goal of the analysis of the problems in question is to popularize knowledge about selected facets of the phenomenon significant from the perspective of public health.

\section{Definition of dietary suplements and legal regulations in Poland and the EU}

According to the Act on Food Safety and Nutrition of 25 August 2006, a dietary supplement is a manufactured product intended to supplement the normal diet, which contains concentrated amounts of vitamins or minerals or other substances with nutritional or other physiological effects, individually or in combination, marketed in dosage forms, such as capsules, tablets, drops, powder bags, liquid ampoules, dropper bottles and other similar forms of liquids and powders designed to be taken in measured small unit quantities, except for the products of therapeutic properties in accordance with the pharmaceutical law regulations [3]. The above means that in cases where balanced diets cannot be used, dietary supplements can support health and maintain homeostasis yet do not have therapeutic properties. Dietary supplements should be approved by the Chief Sanitary Inspectorate (CSI) when notified about launching a new product and presented with a label design. There is, however, no obligation for quality control, clinical trials (as in the case of therapeutic products), studies regarding durability or interactions with medicines. Lack of pharmaceutical surveillance also means lack of monitoring of adverse side effects. The registration of dietary supplements is simple, relatively inexpensive and lasts only about one year. When properly labelled, they can be sold on the market. The labelling requirements are also not complicated (as opposed

\footnotetext{
${ }^{1}$ Department of Clinical Dietetics, Faculty of Health Sciences, Medical University of Lublin, Poland

${ }^{2}$ Chair and Department of Bromatology, Faculty of Pharmacy with Medical Analytics Division, Medical University of Lublin, Poland
} 
to therapeutic products). The labelling of dietary supplements should include: the term "a dietary supplement", names of categories of nutrients or substances characterising the product or their properties, Recommended Daily Intake (RDI), warnings not to exceed RDI, the statement that dietary supplements cannot be used as a substitute for a diversified diet, the statement that dietary supplements should be kept out of the reach of children $[4,5]$. The content of vitamins, mineral ingredients and other substances of nutritional or other physiological effects provided by the manufacturer on the label should be expressed as RDI. The information about vitamin and mineral content should also be given as percentage in relation to RDI. This completes the information which should be provided by manufacturers of dietary supplements. Since there are no legal requirements regarding leaflets for patients, such leaflets are usually not attached [4-7]. It needs to be stressed that for the majority of people advertisements are the key source of information about dietary supplements. They should not claim or imply that a diversified and balanced diet cannot provide sufficient amounts of nutrients. Moreover, dietary supplements should not be identified with the properties enabling prevention or treatment of diseases and such properties should not be even referred to. Nevertheless, advertising designers do not always follow the above rules and associate a given supplement with a particular disease and consider it an agent indispensible for disease prevention and health improvement $[4,5]$.

The legal requirements for dietary supplements entering the Polish market are defined by the following law regulations:

1. Act on Food Safety and Nutrition of 25 August 2006 (Journal of Laws 2015, item 594).

2. Directive of the Minister of Health of 9 October 2007 on composition and labelling of dietary supplements (Journal of Laws, item 453, as amended).

3. Regulation (EU) No. 1169/2011 of the European Parliament and the Council of 25 October 2011 on the provision of food information to consumers, amending Regulations (EC) No. 1924/2006 and (EC) No.1925/2006 and repealing Commission Directive 87/250/EEC, Council Directive 90/496/EEC, Commission Directive 1999/10EC, Directive 2000/13/EC of the European Parliament and the Council, Commission Directives 2002/67/EC and 2008/5/EC and Commission Regulation (EC) No. 608/2004 (Official Journal (OJ) L 30422.11 .2011 p. 18, as amended).

4. Regulation (EC) No. 1924/2006 of the European Parliament and the Council on nutrition and health claims made on food (correction OJ 12, 18.01.07, p. 3).

5. Regulation (EU) No. 432/2012 of 16 May 2012 establishing a list of permitted health claims made on food, other than those referring to the reduction of disease risk and to children`s development and health (OJ L 136, p.1).

6. Regulation (EC) No. 1333/2008 of the European Parliament and the Council of 16 December 2008 on food additives (OJ L 354 of 31.12.2008, p.16, as amended).

7. Regulation (EC) No. 1334/2008 of the European Union and the Council of 16 December 2008 on flavourings and certain food ingredients with flavouring properties for use in and on foods and amending Council regulation (EEC) No. 1601/91, Regulations (EC) No. 2232/96 and (EC) No.110/2008 and Directive 2000/12 /EC (OJ L 354 of 31.12.2008, p. 34 as amended).

8. Regulation (EC) No. 178/2002 of the European Parliament and the Council of 28 January 2002 laying down the gen- eral principles and requirements of food law, establishing the European Food Safety Authority and laying down procedures in matters of food safety (OJ L 31 of 1 February 2002, p.1, as amended).

9. Commission regulation (EC) No. 1881/2006 of 19 December 2006 setting maximum levels for certain contaminants in foodstuffs (OJ L 364 of 2006, as amended).

10. Commission regulation (EC) No. 1170/2009 of 30 November 2009 amending Directive 2002/46/EC of the European Parliament and the Council as regards the lists of vitamins and minerals and their forms that can be added to foods, including food supplements (OJ L 314, p.36).

11. Regulation of the Minister of Health of 23 March 2011 establishing standards of new-to-market products, including product registration and an approved list of national scientific bodies authorised to issue related opinions (Journal of Laws item 2011, No. 80 of 18 May 2017).

12. Regulation of the Minister of Health of 24 April 2017 amending the regulation on composition and labelling of dietary supplements (Journal of Laws of 18 May 2017).

13. Regulation of the Minister of Health of 17 November 2017 amending the regulation on composition and labelling of dietary supplements ( Journal of Laws item 2236 of 4 December 2017).

\section{The use of dietary supplements in Poland: the scale of the phenomenon from the perspective of public health}

The Polish market of dietary supplements is developing very dynamically. In 2015, the Polish consumers spent 3.5 billion PLN for dietary supplements, purchasing almost 190 million packets. A statistical Polish citizen bought six packets of dietary supplements, spending about 100 PLN. The Registry of the Chief Sanitary Inspectorate includes almost 30.000 products notified as dietary supplements. The studies show that in the years 2017-2020, this market will be increasing by about $8 \%$ a year. The development of the market of dietary supplements is markedly affected by advertising, because these products are aggressively marketed and advertised. According to the data of the National Broadcasting Council, between 1997 2015 , the number of commercials regarding health-related products and drugs (including dietary supplements) increased almost twenty times while their total number only three times [5]. In some cases, one may have the impression that advertisements of dietary supplements create new health issues. As a result of aggressive advertising, consumers are convinced that they should consume the highest possible amounts of supplements to maintain and restore health $[4,8]$.

From the perspective of social science, the use of dietary supplements belongs to the concept of illness behaviour [9]. According to W. C. Cockerham, the most common form of illness behaviour is self-care involving preventive measures, self-treatment of symptoms and managing chronic conditions [10]. According to the definition of self-care formulated for the purposes of the research project "A cost/benefit analysis of self-care systems in the European Union" carried out by the European Commission, "self-care is what individuals, families and communities do with the intention to promote, maintain, or restore health and to cope with illness and disability with or without the support of health professionals [...]. It includes but is not limited to self-prevention, self-diagnosis, self-medication and self-management of illness and disability" [11]. Thus, 
the use of dietary supplements meets the criteria of self-care defined in the European systems of health protection. Analyses of self-care (including the European Commission report, mentioned above) performed from a public health perspective point out potential benefits and negative consequences of selfcare, e.g. generation of interactions causing adverse health effects; moreover, the aim of practical activities is to maximise health benefits at the population level and simultaneously minimise the risk of negative health effects [12]. Considering the above, it seems important to discuss the self-care trends observed in the Polish society. The representative studies of the Centre for Social Opinion Research (CSOR) of 1998 and 2010 demonstrate a significant decrease in the use of OTC drugs and pharmaceutical agents as the only response to illness or symptoms ( $45 \%$ of respondents in 1998 versus $24 \%$ in 2010; CSOR does not differentiate OTC drugs and supplements considering them as one category of pharmaceutical agents available without prescription) $[13,14]$. The above findings seem inconsistent with the data, which reveal that the market of dietary supplements and OTC drugs in Poland is increasingly large. However, the discrepancies can be explained based on the analysis, in which the option of combining drugs prescribed by physicians with OTC pharmaceutical agents was taken into account. During 12 months preceding the 2010 study, this form of response to symptoms was used by $61 \%$ of respondents (sic!) as compared to $10 \%$ using only prescription drugs and $19 \%$ using only OTC agents [14]. The results of the "The Polish OTC consumer" study carried out by IPSOS for 2010 are comparable; within one year preceding the study $73 \%$ of respondents used pharmaceutical agents available without prescription and for only $21 \%$ this was the only strategy of management in response to health problems [15]. The newest study by CSOR about OTC drugs and dietary supplements of 2016 demonstrates an increase in the use of OTC drugs and dietary supplements in combination with prescription drugs as the strategy of illness behaviours ( $65 \%$ of adults) and a further decrease in using OTC pharmaceutics as the only self-care strategy (21\% of respondents versus $24 \%$ in 2010 [16]. The above results show a potential risk of interactions which increases with each new preparation used, especially that $53 \%$ of respondents in 2010 stated that they have never consulted the first use of a new OTC agent with a physician and $26 \%$ did it only from time to time [14].

Considering the above data, the recommendations of the European Commission report are worth discussing. According to them, a precondition for safe and effective use of self-care in health protection is empowerment which includes the provision of reliable and comprehensible information about safe and effective use of self-care to maintain health and manage illnesses. Moreover, the report explicitly stresses that self-care does not replace the health care provided by professionals [11]. Since the combined use of prescription drugs and preparations available without prescription is increasingly common, it is crucial to provide reliable information about the health risks associated with polypragmasia and about the treatment options for the most common health problems [verified within the Evidence-Based Medicine (EBM) paradigm], as part of wider strategies aimed at improving health literacy of Polish society.

\section{Classification of dietary supplements from the perspective of nutrition science}

Several groups of dietary supplements containing the ingredients that affect the individual systems and organs are distinguished. According to the mechanism of action, dietary supplements are classified into the following categories [17-21]:

- Dietary supplements supporting weight loss - whose producers declare that they support the process of fatty tissue reduction. Due to the lack of reliable clinical trials regarding the efficacy of such supplements, it is difficult to explicitly determine their beneficial effects. The most common ingredients of such supplements are: inulin, chitosan, caffeine, chromium compounds, dietary fibre, hydroxycitric acid, guar gum, L-carnitine, pineapple and tea extracts, green coffee extracts with conjugated linoleic acid (CLA) [22,23].

- Dietary supplements affecting the locomotor system i.e. preparations containing glucosamine, chondroitin and methylsulphonylmethane (MSM).

- Dietary supplements supporting the immune system containing vitamins, minerals, polyphenols, probiotics and bee products.

- Dietary supplements improving concentration and vitality - containing inositol, choline, caffeine, lecithin, taurine, magnesium, zinc and selenium compounds, amino acids and other active ingredients.

- Dietary supplements supporting the digestive system - containing probiotics and prebiotics, digestive enzymes, herbal extracts, e.g. camomile, peppermint, milk thistle, dill, linseed or lavender flowers.

- Dietary supplements affecting the skin, hair and nails (nutricosmetics) - common horsetail (source of flavonoids, potassium and silicon and common aloes (Aloe vera extracts).

- Dietary supplements affecting the nervous system, concentration and vitality (delaying ageing) - all the preparations containing antioxidants, e.g. vitamins A, C and E [24], polyphenols (catechins, saponins, glycosides), caffeine, choline, inositol, taurine, lecithin, co-enzyme Q, active components derived from ginseng, guarana, magnesium, zinc and selenium compounds.

- Dietary supplements affecting the cardiovascular system stanols, plant sterols, lecithin, unsaturated fatty acids n-3 and n-6, ginkgo and hawthorn extracts.

- Dietary supplements supporting proper vision - with carotenoids (carotenes, cryptoxanthin, lutein and zeaxanthin) and antocyanates (Vacciunium myrtilus)

- Dietary supplements for sportsmen - used to improve their performance by stimulating the generation of energy, increasing muscle strength and mass. This group contains amino acids, medium-chain fatty acids, glucosamine, carnitine, caffeine, CLA, creatinine, $\beta$-hydroxy- $\beta$-methylbutyrate (HMB), shark cartilage, vitamins and minerals.

- Dietary supplements and neoplastic diseases - used to reduce the risk of cancers (although there is no sufficient evidence confirming the correlation between dietary supplements and cancer); preparations containing calcium and selenium compounds, vitamin D, E and C, folic acid.

- Dietary supplements for children - mainly containing vitamin D, K, thiamine, niacin, DHA, copper, calcium, zinc and iron compounds.

- Dietary supplements reducing the risk of osteoporosis the main components of this group are calcium compounds 
and vitamin D. Dietary supplements are also be classified according to their composition [17-19,25]:

- Dietary supplements containing vitamins and minerals. All preparations containing vitamins and microelements that are to supplement their deficits in the body are included in this category. According to the valid legislation, the supplements can contain vitamin A, D, E, K, C, B6, B12, thiamine, riboflavin, niacin, pantothenic acid, biotin, foliates, and mineral ingredients: calcium, magnesium, sodium, potassium, phosphorus, copper, zinc, iron, iodine, manganese, selenium, chrome, molybdenum, silicon, boron, fluorides, chlorides. The deficits of any of them can lead to adverse physiological or morphological changes. Vitamins and minerals play an extremely important role in the human body. Unfortunately, our knowledge about the requirements for them is insufficient. To use such supplements, it is useful to have information regarding medium, recommended and safe levels of their intake. The information provided by producers about the content of vitamins and minerals should include: the upper safe level of vitamins and microelements determined on the basis of generally accepted scientific data, intake of vitamins and minerals with other diet sources and recommended intake of vitamins and minerals for the population $[21,26]$.

- Dietary supplements with plant components and extracts, containing isolated active substances, whose main action is to improve immunity and strengthen functioning of the individual organs. Their efficacy is strictly correlated with the presence of certain active compounds in their composition. These include plant-derived substances, such as primary metabolites, i.e. starch, simple sugars, amino acids, fatty acids, mucus and secondary metabolites consisting of sugary and non-sugary part typical of a given active compound, e.g. flavonoids, alkaloids, tannins, terpenes. These supplements are most commonly produced from raw plant materials and extracts of plants of no potent pharmacological effects. The doses of active substances are multiple times lower than the typical therapeutic doses. In the past, the plants traditionally occurring in Europe were used. At present, also the plants derived from the traditional Chinese medicine are increasingly common, such as lychee, ginkgo and Sarcodontia Schulzer. The valuable herbal ingredients of some dietary supplements are also hawthorn, purple coneflower (Echinacea purpurea), ginseng, garlic and commonly used spices (ginger, fennel, cinnamon, marjoram, pepper, basil, oregano) [27].

- Dietary supplements containing indispensible unsaturated fatty acids, which are to supply the body with deficient fatty acids, i.e. omega- 3 fatty acids (n-3). Their main source is fatty sea fish, e.g. salmon, herring, mackerel or tuna fish. The studies have demonstrated that n-3 fatty acids have anti-inflammatory, antiarrhythmic, antiaggregative and hypotensive effects. Therefore, n-3 fatty acids are valuable dietary components. Moreover, they have been shown to exert positive effects on the lipid profile, increasing the concentration of HDL cholesterol and reducing the level of triglycerides in serum. The plant sources of fatty acids in dietary supplements are mostly borage and evening primrose. The oils from these plants can have various positive functions. Borage oil is rich in organic acids (e.g. malic, ascorbic, citric), tannins, flavonoids (quercetin, kaempfrol), saponins and minerals. Moreover, gamma-linolenic acid
(GLA) in this oil is an important building material for cells and it regulates metabolism. Evening primrose oil contains unsaturated fatty acids which alleviate skin allergies, improve adipose tissue metabolism and relieve the symptoms of premenstrual syndrome.

- Dietary supplements containing dietary fibre - plant fibre is a valuable component of many food products. The majority of its ingredients belong to the group of carbohydrates, which are indigestible and unabsorbable in the gastrointestinal tract. This accelerates intestinal peristalsis and filling, which prevents constipations and promotes the development of proper microbiota. Preparations with fibre can supplement the diets, especially during the process of obesity treatment. Fibre with water forms gels, which hinder the absorption of glucose in the small intestine and reduce postprandial glycaemia. Moreover, the soluble fibre fraction helps to reduce serum triglyceride and LDL-cholesterol levels.

- Dietary supplements containing probiotics and prebiotics - microorganisms of probiotic action are mainly bacteria from the genera Lactobacillus and Bifidobacterium. Prebiotics are natural indigestible ingredients of food, which selectively stimulate the growth and activity of bacteria in the large intestine. The prebiotic compounds include some proteins, peptides, fats, oligo- and polysaccharides and are found in onion, garlic, potatoes, bananas, chicory and leek.

- Supplements containing amino acids. Amino acids and their derivatives used in dietary supplements include arginine, taurine, methionine, glutamine, citrulline, creatinine and Lcarnitine. Dietary supplements with amino acids are mostly designed for individuals performing strenuous and physically demanding tasks, especially sportsmen.

\section{Recommendation on the use of dietary supplements}

According to current knowledge, the use of dietary supplements is indicated in the following cases [1,20,28,29]:

- in sportsmen due to physically demanding tasks and increased nutrient requirements (depending on sex, age, sports practiced, the intensity and duration of physical effort - in the amount not exceeding the set upper limit /UL/) [30];

- in pregnant women who should take supplements containing folic acid and iron as well as calcium, iodine, other minerals and vitamins (yet only in justified cases) [29,31,32];

- in post-menopausal women as reduced concentrations of estrogens are associated with bone mass loss, what leads to osteoporosis; therefore, in cases where the supply of calcium and vitamin $\mathrm{D}$ is insufficient, it is recommended to use them as supplements [33];

- in adults consuming less than 1600 calories a day as it is highly unlikely that vitamin and mineral requirements are covered in this situation;

- in the elderly who may require supplementation with some vitamins and minerals, particularly when their diets are not well-balanced and the daily energy value is below 1500 kcal;

- in individuals on restriction or elimination diets (e.g. excluding all dairy products, when the requirements for calcium, vitamin D and others cannot be fully covered), including vegetarians and vegans [29]. 


\section{Selected sefaty issues taking legal and institutional solutions intoaccount}

When analyzing the issue of the safety of dietary supplements, attention will be focused on the state of knowledge in this field in the Polish society and on the determinants of the current situation in this area. On the basis of the analyzed state of research we seem to be dealing with serious deficits in this field. According to a poll conducted in 2014 by TNS Polska, only $27 \%$ of adult Poles are aware that dietary supplements should be treated as a supplement to the daily diet. Moreover, many people mistakenly consider supplements as "vitamins" $(31 \%)$ or "minerals" $(8 \%)$ and $41 \%$ of respondents wrongly attributed the therapeutic effects to dietary supplements. About one fourth of the subject also believes that a dietary supplemented cannot be overdosed [34]. When interpreting the cited results, it should be pointed out that the commercials are partially to blame as they use the image of a physician recommending a particular product/dietary supplement as efficient, of unique composition and action, what is misleading for consumers; thus, it is not surprising that the majority of consumers do not distinguish dietary supplements from medicines $[8,35]$. Labelling, presentation and advertising of dietary supplements cannot be misleading, particularly with regard to their characteristics (including the name, type, properties, amount, durability, source, methods of production) and should not attribute the action or properties to a given dietary supplement that it does not have, or suggest that the agent has special properties, if all similar food products have such properties and that it can prevent or treat diseases [21]. The problem is also that dietary supplement packets do not contain information about adverse side effects, contraindications and interactions when used together with prescription and OTC drugs. Attention should also be drawn to selected problems concerning labelling. Dietary supplements should be launched, presented and advertised under the name of " a dietary supplement", which cannot be replaced with a trade name of this food product. A trade name can be used as additional labelling and the term "a dietary supplement" should be placed in the vicinity of it. However, in many cases, the term "dietary supplement", although placed in the vicinity of a given trade name, is written in a smaller font, sometimes blurred and poorly visible. This is also observed in some commercials concerning dietary supplements [5]. From the perspective of pharmaceutical sciences, the problem of growing significance is the simultaneous use of dietary supplements and drugs, what can impair the therapeutic process and increase the risk of adverse effects as in many cases patients do not inform their physicians about dietary supplements they use, considering them irrelevant. Supplements can change the action of the drugs used, e.g. by reducing the absorption of antibiotics, anticonvulsants, cardiac preparations and many others and by increasing their excretion, or by impairing metabolism and inducing other adverse effects. The interactions can occur between plant preparations and drugs (e.g. St John's wort, gingko, garlic, kava, ginseng, valerian, aloes, grapefruit flavonoids versus statins, hypertensive, antihistamine or immunosuppressive drugs), between vitamin supplements and drugs (e.g. niacin, folic acid, vitamin C, B6, E, K versus coumarins, barbiturates, warfarin) as well as between mineral ingredients and drugs (e.g. magnesium, calcium and iron versus antibiotics and diuretics) $[1,36]$. Dietary supplements can also be adulterated with chemical compounds not listed by producers and not approved for sale (e.g. amphetamine, sibutramine, ephedrine, diuretics, laxatives, antidepressants or anxiolytics were found in the dietary supplements used for slimming and caused intoxications) [4,5,37-39]. The laboratory studies ordered by the Supreme Audit Office (in Polish: Najwyższa Izba Kontroli, NIK) have demonstrated that many dietary supplements do not have the features declared by their producers. Among the preparations available online, in stores and pharmacies, there were some fraudulent dietary supplements that contained pathogenic bacteria, prohibited substances (from the list of psychoactive preparations) or stimulants structurally similar to amphetamine [5].

While looking for possible solutions aimed at increasing the level of knowledge about the rules of use and safety of dietary supplements, one should point out the potential in health risk education, connected with the leaflet enclosed with particular pharmaceutical agents. Regrettably, in Poland there is no legal obligation to enclose a leaflet with products categorized as dietary supplements. Studies show, however, that $62 \%$ of individuals using pharmaceutical preparations systematically read the information provided in leaflets (if they are enclosed with a product) $(25 \%$ - sometimes and $13 \%$ - never $)$ [14]. According to the 2016 study, leaflets are always read by $69 \%$ of respondents (19\% - sometimes) and 1/3 of adults search for information on the Internet (29\%) [16]. The data of 2016 seem optimistic; at least one source of information is used by $91 \%$ of respondents and $62 \%$ use two and more sources of information [16].

In the area of institutional solutions, we should point out the initiative of the National Medicines Institute, which established the Therapeutic Plant Products and Dietary Supplements Cluster which grants Quality Certificates. The aim of granting such certificates is to promote the products of documented and confirmed quality and safety [40]. At the European Union level, in order to eliminate the sources of hazards associated with intake of food potentially dangerous for health, the European Union implemented the Rapid Alert System for Food and Feed (RASFF). This is a notification system aimed to exchange information on food, feed and materials intended for food contact, which are potentially hazardous to human and animal health and to the environment, and on the actions undertaken to identify such products [41]. One designated contact point exists for each member of the RASFF network. In Poland, in accordance with the Act on Food and Nutrition Safety (Art. 85), the Chief Sanitary Inspectorate is responsible for the RASFF network, runs the national contact point (NCP) and notifies the European Commission about the cases of dangerous food and feed. According to the Regulation (EU) No. $16 / 2011$, the aim of the NCP in the Chief Sanitary Inspectorate as a member of the RASFF network is to ensure effective functioning of the network and effective communication in Poland. The basis for undertaking all the actions and decisions within the RASFF is the legislation regarding food, feed, materials and products intended for food contact as well as the scientific evaluation of the risks associated with consumption of dangerous food and feed. Based on their appropriate competences, the respective Polish authorities control food, feed, as well as materials and products intended for food contact to determine whether the food and feed entrepreneurs responsible for provision of safety fulfil the requirements defined in food and feed law. Once the hazardous products have been identified, local actions are immediately undertaken to eliminate the risk of their consumption and the NCP in the Chief 
Sanitary Inspectorate is provided with all the necessary information. The NCP in the Chief Sanitary Inspectorate cooperates with the food and feed control authorities, the European Commission and other members of the RASFF network, providing and receiving information about the detected dangerous products, what enables taking all the appropriate actions and thereby protecting the consumers' health $[41,42]$.

\section{CONCLUSIONS}

The borderline between the use of dietary supplements when required and their unjustified use is blurred. Dietary supplements should be used to reduce the risk of nutrient deficiencies when the diets covering all nutritional requirements cannot be provided. However, whenever diet supplementation is considered, it is crucial to analyse and determine eating habits, general health status, health-related contraindications, history of diseases, drugs and therapies used, etc.

\section{REFERENCES}

1. Brzozowska A, Olędzka R. Suplementacja diety jako droga do poprawy stanu odżywienia i stanu zdrowia ludności. In: J. Gawęcki, W. Roszkowski (ed). Żywienie człowieka a zdrowie publiczne. Cz. 3. Warszawa: PWN; 2009. p. 313-28.

2. Bojarowicz H, Dźwigulska P. Suplementy diety. Cz. I. Suplementy diety a leki - porównanie wymagań prawnych. Hygeia Public Health. 2012;47(4):427-32.

3. Ustawa z dnia 25 sierpnia 2006 r. o bezpieczeństwie żywności i żywienia. Dz. U. z 2015 r., poz. 594.

4. Wróbel-Harmas M, Krysińska M, Postupolski J, Wysocki MJ. Zagrożenia związane ze stosowaniem suplementów diety w świetle analizy danych z Internetu i doniesień systemu RASFF. Prz Epidemiol. 2014;68:613-9.

5. Raport NIK o dopuszczaniu do obrotu suplementów diety z dnia 10 lutego 2017r. [https://www.nik.gov.pl/.../nik-o- dopuszczaniu-do-obrotusuplementow-diety.htm] (dostęp 1.06.2018r.)

6. Główny Inspektorat Sanitarny (GIS): [http://suplementy.gis.gov.pl/] (dostęp 1.06.2018r.)

7. Brzozowska A, Roszkowski W, Pietruszka B, Kałuża J. Witaminy i składniki mineralne jako suplementy diety. Żywność. Nauka. Technologia. Jakość. 2005;4(45):5-16

8. Wierzejska R. Suplementy diety - panaceum na współczesne dolegliwości zdrowotne czy triumf reklamy? Med Rodz. 2017;20(2):136-42.

9. Mechanic D. Sociological dimensions of illness behaviour. Soc Sci Med. 1995;41(9):1207-16.

10. Cockerham WC. Medical sociology. New Jersey: Prentice Hall; 2004. p. $118-40$.

11. Ostermann H, Renner A-T, Bobek J, et al. A cost/benefit analysis of selfcare systems in the European Union. Final report. European Commission, European Union; 2015.

12. Krajewski-Siuda K, Łach K. Samoleczenie - definicja problemu w kontekście nowych trendów społecznych. In: K. Krajewski-Siuda (ed) Odpowiedzialne i nowoczesne samoleczenie w systemie ochrony zdrowia. Warszawa: Fundacja Obywatele Zdrowo Zaangażowani; 2016. p. 8-13.

13. Komunikat $\mathrm{z}$ badań CBOS BS/52/98. Leczenie się domowymi sposobami. CBOS, Warszawa, kwiecień 1998: 1-7.

14. Roguska B, Feliksiak M. Stosowanie leków dostępnych bez recepty. Komunikat CBOS nr BS/143/2010. Warszawa: Fundacja CBOS; październik 2010. p. 1-15.

15. Borek E. Dessoulavy-Gładysz I. Samoleczenie i samoopieka w Polsce w kontekście trendów europejskich. Analiza porównawcza. In: K. Krajewski-Siuda (ed). Odpowiedzialne i nowoczesne samoleczenie w systemie ochrony zdrowia. Warszawa: Fundacja Obywatele Zdrowo Zaangażowani; 2016. p. 28-33

16. Feliksiak M. Leki dostępne bez recepty i suplementy diety. Komunikat z badań CBOS nr 158/2016. Warszawa: Fundacja CBOS; listopad 2016. p. 1-16.

17. Jarosz M, Respondek W. Suplementy diety a zdrowie. Porady lekarzy i dietetyków. Warszawa: Wydawnictwo Lekarskie PZWL; 2008
18. Bojarowicz H, Dźwigulska P. Suplementy diety. Cz. II. Wybrane składniki suplementów diety oraz ich przeznaczenie. Hygeia Public Health. 2012;47(4):433-41.

19. Jarosz M. Suplementy diety - korzyści i zagrożenia. Warszawa: IŻŻ; 2009.

20. Dymkowska-Malesa M. Suplementacja w sporcie. Now Lek. 2011;80(3):199-204

21. Krasnowska G, Sikora T. Suplementy diety a bezpieczeństwo konsumenta. Żywność. Nauka. Technologia. Jakość. 2011;4(77):5-23.

22. Nachtigal MC, Patterson RE, Stratton KL, et al. Dietary supplements and weight control in a middle-age population. J Altern Complement Med. 2005;11(5):909-15.

23. Yazaki Y, Faridi Z, Ma Y, et al. A pilot study of chromium picolinate for weight loss. J Altern Complement Med. 2010;16(3):291-9.

24. Rozporządzenie Ministra Zdrowia z dnia 24 kwietnia 2017 r. zmieniające rozporządzenie w sprawie składu oraz oznakowania suplementów diety (Dz. U z 18 maja 2017r., poz. 979).

25. Jarosz M. Suplementy diety a zdrowie. Warszawa: PZWL; 2008.

26. Jarosz M. Normy żywienia dla populacji Polski. Warszawa: IŻŻ; 2017.

27. Schlegel-Zawadzka M, Barteczko M. Ocena stosowania suplementów diety pochodzenia naturalnego $w$ celach prozdrowotnych przez osoby dorosłe. Żywność. Nauka. Technologia. Jakość. 2009;4(65):375-87.

28. Szcześniak P, Szuszkiewicz J, Michalak Ł. Orszulak-Michalak D. Żywienie i suplementacja diety w wieku podeszłym. Farm Pol. 2009;65(11):775-9.

29. Stoś K, Wierzejska R, Siuba-Strzelińska M. Rola suplementów diety w realizacji norm. In: M. Jarosz (ed). Normy żywienia dla populacji Polski. Warszawa: IŻŻ; 2017. p. 301-16.

30. Thomas DT, Erdman KA, Burke LM. Nutrition and athletic performance. Medicine \& Science in Sports \& Exercise. Official J ACSM. 2016:543-68.

31. Rekomendacje Polskiego Towarzystwa Ginekologicznego w zakresie stosowania witamin i mikroelementów u kobiet planujących ciążę, ciężarnych i karmiących. Ginekol Pol. 2014;85:395-9.

32. WHO Guidelines. Calcium supplementation in pregnant women. Geneva World Health Organization; 2013.

33. Buczkowski K, Chlabicz S, Dytfeld J, et al. Wytyczne dla lekarzy rodzinnych dotyczące suplementacji witaminy D. Zalecenia opracowane przez Polską Grupę Roboczą International University Family Medicine Club. Forum Med Rodz. 2013;7(2):55-8.

34. „Świadome samoleczenie w Polsce - www.lekiczysuplementy.pl 2014”. TNS Polska. [www.rynekzdrowia.pl] (dostęp 13.07.2018 r).

35. Wierzejska R. Czy reklama suplementów diety jest obiektywnym źródłem informacji o ich wpływie na zdrowie. Analiza reklam radiowotelewizyjnych w świetle przepisów prawa żywnościowego. Wiad Lek. 2016;69(1):14-8.

36. Bojarowicz H, Dźwigulska P. Suplementy diety. Cz. III. Interakcje suplementów diety z lekami. Hygeia Public Health. 2012;47(4):442-7.

37. Łukasik-Głębocka M, Sommerfeld K, Teżyk A, Zielińska-Psuja B. Ostre zatrucie suplementem diety wspomagającym odchudzanie fałszywie sugerujące użycie amfetaminy. Prz Lek. 2013;70(10):1-4.

38. Kujawa A, Szponar J, Szponar E, et al. Szkodliwość leków i środków wspomagających odchudzanie - punkt widzenia toksykologa. Prz Lek. 2012;69(8):548-51.

39. Wiergowski M, Galer-Tatarowicz K, Nowak-Banasik L, et al. Zagrożenie dla zdrowia i życia ludzkiego przez nieświadome zastosowanie syntetycznej sibutraminy sprzedawanej jako chiński preparat ziołowy "Meizitanc". Prz Lek. 2007;64(4/5):268-72.

40. [www.klasterzdrowia.pl] (dostęp 1.06.2018 r.)

41. [https://ec.europa.eu/food/safety/rasff_en] (dostęp 1.06.2018 r.)

42. [www.nowoczesnerolnictwo.info/.../system-wczesnego-ostrzegania-oniebezpiecznej-zywnosci/] (dostęp 1.06.2018 r.).

\section{Corresponding author}

Dr Agnieszka Marzec

Deptartment of Clinical Dietetics, Faculty of Health Sciences

Medical University of Lublin

1 Chodźki St., 20-093 Lublin

E-mail: agnieszkamarzec@umlub.pl 